\title{
Preliminary observations on the patterns of co-occurrence of Black fly (Diptera: Simuliidae) larvae and some of their potential macroinvertebrate predators
}

\author{
Ronaldo Figueirón ${ }^{1,2,3 *}$ (1), Suzana Silva dos Santos ${ }^{1}$, \\ Tatiana Nascimento Docile ${ }^{1,4,5}$, Tayanna Rodrigues da Costa ${ }^{1}$, \\ Christina de Albuquerque Ferreira, Leonardo Henrique Gil-Azevedo ${ }^{6}$
}

\author{
${ }^{1}$ Fundação Centro Universitário Estadual da Zona Oeste (UEZO), Rio de Janeiro, RJ, Brasil. \\ ${ }^{2}$ Centro Universitário de Volta Redonda (UNIFOA), Volta Redonda, RJ, Brasil. \\ ${ }^{3}$ Universidade Castelo Branco (UCB), Rio de Janeiro, RJ, Brasil. \\ ${ }^{4}$ Universidade do Estado do Rio de Janeiro (UERJ), Instituto de Aplicação Fernando Rodrigues da Silveira (Cap-UERJ), Rio de Janeiro, RJ, Brasil. \\ ${ }^{5}$ Fundação Oswaldo Cruz (FIOCRUZ), Escola Politécnica de Saúde Joaquim Venâncio, Laboratório de Educação Profissional em \\ Vigilância em Saúde (LAVSA), Rio de Janeiro, RJ, Brasil. \\ ${ }^{6}$ Universidade Federal do Rio de Janeiro (UFRJ), Museu Nacional, Departamento de Entomologia, Rio de Janeiro, RJ, Brasil.
}

\section{A R T I C L E I N F O}

Article history:

Received 19 May 2020

Accepted 4 August 2020

Available online 4 September 2020

Associate Editor: Gustavo Graciolli

\section{Keywords:}

Aquatic insects

Community

Predation

Simulids

\begin{abstract}
A B S T R A C T
Biotic factors such as predation, although important drivers of the black fly community, are rarely investigated in the literature. This study aimed to test the hypothesis that the patterns of co-occurrence of black fly larvae and its potential predators is not random and that there is a correlation between its frequencies and Simuliidae larvae abundances. Larvae were sampled from two localities in the Pedra Branca State Park, Rio de Janeiro, Brazil, during the dry season in june 2018. We collected Simulium pertinax Kollar, 1832, Simulium subpallidum Lutz, 1910, Simulium (Inaequalium) sp., Simulium (Psaroniocompsa) sp. and Simulium (Trichodagmia) sp. The predators families present were Perlidae, Hydropsychidae, Leptoceridae, Libellulidae and Chironomidae. The null models showed that species co-occurred significantly more than expected by chance. The canonical correlation analyses for the Vargem Grande and Pau da Fome areas area showed a significant relationship between black fly abundances and predator abundances. In Vargem Grande the abundance of Chironomidae showed a highly significant positive correlation to $S$. (Psaroniocompsa) sp., while Hydropsychidae was significantly correlated to Simulium sp. On the other hand, in Pau da Fome Libellulidae was significantly correlated to S. (Psaroniocompsa) sp. and Simulium sp. and Chironomidae correlated significantly to Simulium sp. The result is consistent with what would be expected of organisms that exercise mutual population regulation, although other factors than biotic interactions may be causing these patterns. However the lack of mechanistic evidences on the effect of biotic interactions on black fly populations pose a challenge on the understanding of these patterns.
\end{abstract}

Aquatic insects play an important role in the trophic relationships of freshwater systems (Garcia-Domingo and Saldaña, 2008), as they participate in various processes, such as the cycling of matter and energy flow (Cummins, 1992; Allan, 1995). Among the aquatic insects, a very abundant group in the streams are the black flies (Diptera, Simuliidae). This family contains 2,310 described species (Adler, 2019). Black flies are pests of humans and domestic animals and vectors of bird and mammal parasites (Adler et al., 2004), some species act as vectors of human diseases such as Onchocerciasis (Rey, 2001; Luz et al., 2014).

In the southern and southeastern regions of Brazil, there is no report of disease transmission by these insects, but the high rates of stinging by hematophagous species in areas of occurrence cause great discomfort in the population (Figueiró and Gil-Azevedo, 2010). Their larvae, however, play a key functional role in flowing waters (Malmqvist et al., 2004). Use their labral fans to filter particulate matter from the water column (Crosskey, 1990). Larvae also scrape material from the substrate, prey on aquatic organisms (Currie and Craig, 1988), and ingest dissolved organic matter (Hershey et al., 1996).

Black flies are ubiquitous organisms, found in most environments with running waters that may harbor their immatures (Currie and Adler, 2008), even though their local occurrence is influenced by a series of local abiotic factors such as substrate type (Hamada et al., 2002; Pepinelli et al., 2005; Figueiró et al., 2012), water flow velocities (Figueiró et al., 2008, 2015), water pollution (Docile et al., 2015, 2016)

\footnotetext{
* Corresponding author.

E-mail: ronaldofigueiro@gmail.com (R. Figueiró).
} 
and altitude (Figueiró et al., 2006; Kuvangkadilok et al., 1999; BuitragoGuacaneme et al., 2018; Cuadrado et al., 2019). Seasonality also plays an important role in the distribution of black flies, with wet and dry seasons influencing local (Srisuka et al., 2015; Pavitra et al., 2020) and regional diversity patterns (Figueiró et al., 2014).

While the literature on black fly spatial distribution often focus on the influence of seasonality and/or abiotic factors (Rohmah et al., 2018, Hadi et al., 2019), the effect of biotic factors tend to be overlooked, with most of the studies in this perspective concentrating on the influence of parasitism (Ginarte et al., 2003, Araújo-Coutinho et al., 2004, Nascimento et al., 2007) due to its potential use in biological control (Figueiró and Gil-Azevedo, 2010). Predation can have a strong influence on community structure, affecting reproduction, feeding, adaptation to abiotic factors and defense, which are the four basic requirements of animals for survival and perpetuation (Peckarsky, 1984). In Brazil, few works have studied predators of black flies, and much of the existing information has been published in abstracts of papers presented at meetings or theses that are not widely circulated (Alencar et al., 1999).

Biotic factors such as predation (Alencar et al., 1999) and competition (Harding and Colbo, 1981; Hemphill, 1988), although important drivers of the black fly community structure, are rarely investigated in the literature. Thus, the present study held as objective to test the hypothesis that the patterns of co-occurrence of black fly larvae and its potential predators listed in the literature is not random and that there is a correlation between Simuliidae larvae abundances and the abundance of its potential predators.

The study was carried in the Pedra Branca State Park, which is the largest urban park in Brazil (Silva et al., 2019). This park had its creation in 1974 in the Rio de Janeiro municipality and harbors 8 hydrological basins (Vallejo et al., 2009). Due to the existence of these basins within this area its conservation is vital to the water supply of the Rio de Janeiro municipality.

The larvae was sampled from the Divisa/Moinho river, located in the Vargem Grande locality (Site 1: S22 ${ }^{\circ} 50.224^{\prime}$, W043 ${ }^{\circ} 30.157^{\prime}$; Site 2: S22 ${ }^{\circ}$ 57.067', W043 '29.155'; Site 3: S22 ${ }^{\circ} 57.164 '$ ', W043 $29.270^{\prime}$; Site 4: $\left.\mathrm{S} 22^{\circ} 57.166^{\prime}, \mathrm{W}^{\circ} 43^{\circ} 29.268^{\prime}\right)$ and rio Grande river, located in the Pau da Fome locality (Site 5: S22 ${ }^{\circ} 52.922^{\prime}$, W043 ${ }^{\circ} 26.651^{\prime}$, Site 6: S22 ${ }^{\circ} 55.987$ ', W043 26.667 , Site 7: S22 $56.009^{\prime}$, W043 ${ }^{\circ} 26.735^{\prime}$ ) during the dry season in june 2018. While the Divisa/Moinho stream is adjacent to the Quilombola community Cafundá Astrogilda, which implanted an agroforest model of sustainable agriculture, the Rio Grande stream feeds a water catchment station and is located in an area more prone to visitation.

Macroinvertebrates were sampled manually: at each sampling site, which consisted of a $15 \mathrm{~m}$ stream/river section, a random sample of riffle litter from 10 quadrats $(30 \times 30 \mathrm{~cm})$ was taken. This type of sampling was selected in detriment of a surber in order to focus the sampling on black fly distributions and its associated entomofauna that co-occurred in the same substrates.

In order to test if the abundances of black flies was just reflecting the overall macroinvertebrate abundances a spearman correlation coefficient was calculated using black fly larvae counts and all other macroinvertebrate immature counts finding no significant correlation pattern ( $\mathrm{p}=0.3154$, rs $=0.175$ ). After this procedure macroinvertebrate specimens from insect orders that have families described as black fly predators in the literature were separated and then identified down to family level. Individuals from insect families of black fly predators were then identified and quantified using the pertinent literature (Angrisano, 1995; Wiggins, 1996; Carvalho et al., 2002; Olifiers et al., 2004; Pes et al., 2005).

Black fly larvae were sorted into different morphotypes in the laboratory and then identified in species level when possible and in subgenus level when species-level identification was not possible using the taxonomical literature (Hamada and Adler, 2001; Coscarón and Coscarón-Arias, 2007).

The null hypothesis that the co-occurrence pattern of black fly larvae and their potential predators was random was tested using the null modelling software ECOSIM (Gotelli and Entsminger, 2009) to create null models for co-occurrence, in which the C-score index (Stone and Roberts, 1990) with fixed sums for row and fixed column constraints was employed and all taxa with less than 50 individuals were removed according to Gotelli and Ulrich (2012).

Blanchet et al. (2020) recently concluded in their critical review of the use of co-occurrence models in ecology that interactions cannot be directly inferred from the output of these models, and suggest that although presence-absence data are still important to understand species distributions, abundance data could provide a more powerful framework to understand the patterns of occurrence of species. Thus, the relationship between the abundances of black fly larvae and the abundances of their predators was investigated using a canonical correlation analysis (CCorrA), which is a multivariate technique that allows measuring the strength of the relationships between two sets of variables. The first set of variables used in the CCorrA was composed by the abundances of the predator families used in this study (Perlidae, Leptoceridae, Hidropsychidae, Libellulidae, Chironomidae) whereas the second set of variables was comprised of the abundances of the black fly species/subgenera identified in this study. A distinct CCorrA was performed to each of the two areas.

In the Vargem Grande area Simulium pertinax Kollar, 1832, Simulium (Psaroniocompsa) sp. and Simulium (Trichodagmia) sp. were the black flies identified and Perlidae, Hydropsychidae, Leptoceridae, Libellulidae and Chironomidae the potential predator families present, while in Rio Grande S.pertinax, Simulium subpallidum Lutz, 1910, Simulium (Inaequalium) sp., Simulium (Trichodagmia) sp. and Simulium (Psaroniocompsa) sp. were the black flies identified and Perlidae, Hydropsychidae, Libellulidae and Chironomidae were the potential predador families present (Table 1 ).

The null model showed that species co-occurred significantly more than expected by chance (observed index $=116.40000$, mean of simulated indices $=110.30540$, $\mathrm{p}$-value $=0.00280$ ), thus indicating that co-occurrence patterns were not random.

The canonical correlation analysis for the Vargem Grande area showed a highly significant relationship between black fly abundances and predator abundances ( $\mathrm{p}$-value $<0.001$, canonical $\mathrm{R}=0.9098, \mathrm{R} 2=0.8277$ ). The CCorrA for the Pau da Fome area also showed a significant relationship between black fly abundances and predator abundances ( $\mathrm{p}$-value $=0.0021$, canonical $\mathrm{R}=0.9398, \mathrm{R} 2=0.8832$ ). . In both cases only the first canonical variable was significant. These correlations may also reflect that both black flies and their potential predators share the same microhabitat preferences.

The highest canonical loadings in module for the potential predators set in Vargem Grande were Chironomidae (0.8513) and Hydropsychidae (0.4764), while in the set composed by black fly larvae S. (Psaroniocompsa) sp. (0.9149) and Simulium sp. (0.2522) had the highest loadings in module (Table 2). The highest canonical loadings in module for the potential predators set in Pau da Fome were Libellulidae (1.1749) and Chironomidae (-0.6996) while in the set of black fly larvae Simulium (Psaroniocompsa) sp. (0.8781) S. subpallidum(-0.5666) and $S$. (Trichodagmia) sp. (0.5077) were the highest canonical loadings in module (Table 2).

In Vargem Grande the abundance of Chironomidae showed a highly significant positive correlation ( $\mathrm{p}<0.01, \mathrm{r}=0.838$ ) to $S$. (Psaroniocompsa) sp., while Hydropsychidae was significantly correlated to Simulium sp. $(\mathrm{p}<0.01, \mathrm{r}=0.531$ ) (Fig. 1a). On the other hand, in Pau da Fome Libellulidae 
Table 1 Total abundances of Simuliidae larvae and potential predators for the Vargem Grande and Pau da Fome areas.

\begin{tabular}{ccc}
\hline & Vargem Grande & Pau da Fome \\
\hline Black fly species & 22 & \\
S. pertinax & 14 & 48 \\
Simulium sp. & 9 & 27 \\
S. (Psaroniocompsa) sp. & 1 & 174 \\
S. (Trichodagmia) sp. & 0 & 58 \\
S. (Inaequalium) sp. & 0 & 14 \\
S. subpallidum & & \\
Potential predators & 39 & 14 \\
Perlidae & 18 & 15 \\
Hydropsychidae & 4 & 0 \\
Leptoceridae & 2 & 2 \\
Libellulidae & 14 & 55 \\
Chironomidae & &
\end{tabular}

Table 2 Values of the CCorrA canonical loadings for the Vargem Grande and Pau da Fome areas.

\begin{tabular}{|c|c|}
\hline \multicolumn{2}{|c|}{ Vargem Grande } \\
\hline Variables & Canonical loadings \\
\hline S. pertinax & -0.2936 \\
\hline Simulium sp. & 0.9502 \\
\hline S. (Psaroniocompsa) sp. & -0.0613 \\
\hline S. (Trichodagmia) sp. & 0.1512 \\
\hline Perlidae & -0.2508 \\
\hline Hydropsychidae & 0.4764 \\
\hline Leptoceridae & -0.0052 \\
\hline Libellulidae & 0.0082 \\
\hline Chironomidae & 0.8513 \\
\hline \multicolumn{2}{|c|}{ Pau da Fome } \\
\hline Variables & Canonical loadings \\
\hline S. pertinax & 0.0696 \\
\hline Simulium sp. & 0.2019 \\
\hline S. (Inaequalium) sp. & -0.0058 \\
\hline S. (Trichodagmia) sp. & 0.5077 \\
\hline S. (Psaroniocompsa) sp. & 0.8781 \\
\hline S. subpallidum & -0.5666 \\
\hline Perlidae & -0.1205 \\
\hline Hydropsychidae & 0.1895 \\
\hline Chironomidae & -0.6996 \\
\hline Libellulidae & 1.1749 \\
\hline
\end{tabular}

A

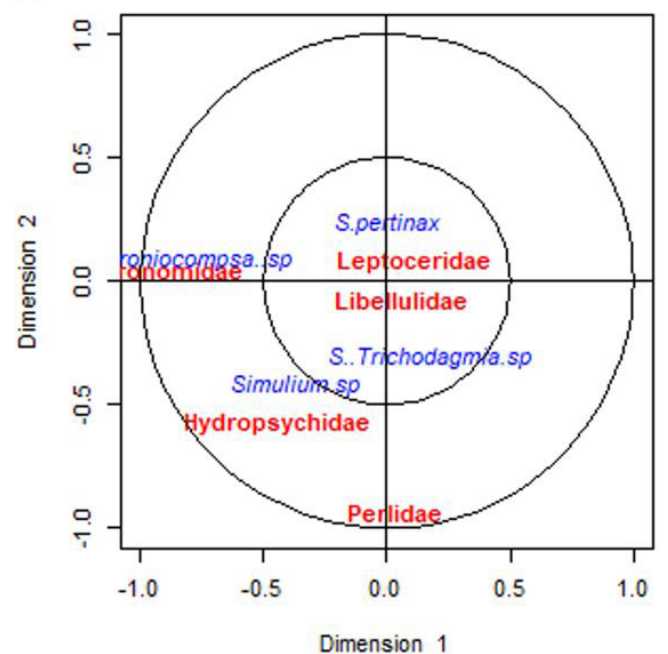

was significantly correlated to $S$. (Psaroniocompsa) sp. $(\mathrm{p}<0.01, \mathrm{r}=0.683)$ and Simulium sp. $(\mathrm{p}<0.05, \mathrm{r}=0.450)$ and Chironomidae correlated significantly to Simulium sp. $(\mathrm{p}<0.01, \mathrm{r}=0.544)$ (Fig. $1 \mathrm{~b})$.

The results of the null models for co-occurence corroborated the hypothesis that the patterns of co-occurrence of Simuliidae and its predators is not random, while the results of the CCorrA corroborate the hypothesis that black fly larvae abundances are correlated to their potential predators.

The CCorrA also suggests that in Vargem Grande Chironomidae are the potential predators with stronger relation to black fly larvae abundances together with Hydropsychidae, while in Pau da Fome Libellulidae were the potential predators with stronger relation to black flies, although Chironomidae also showed strong association to black flies.

This analysis also indicates that in Vargem Grande Chironomidae is more associated to $S$. (Psaroniocompsa) sp., but it is important to remark that these organisms are reported in literature as predators of black fly eggs, not larvae (Crosskey, 1990; Werner and Pont, 2003), and that this insect family has extremely diverse feeding habits. In this same area Hydropsychidae was correlated basically to Simulium sp., which may suggest that it feeds primarily on this subgenus. On the other hand, the results of the CCorrA performed for the Pau da Fome data indicates that potential predation by Libellulidae sould be probably more generalistic, possibly occurring on Simulium sp. and S. (Psaroniocompsa) sp., which showed significant correlations to libellulidae.

Perlidae nymphs are known in the literature to be generalist predators, feeding on several macroinvertebrate groups such as Simuliidae, Chironomidae, Ephemeroptera and Trichoptera (Siegfried and Knight, 1976; Alencar et al., 1999), probably due to their great energy demands during their rapid growth immature stages (Cummins and Klug, 1979). However, Gamboa et al. (2009) observed that black fly larvae accounted for aproximately $20 \%$ of the diet of four Anacroneuria (Plecoptera: Perlidae) in the Andes, so Simuliidae actually may represent a small fraction of its feeding, so the absence of significant correlations in this study can be a reflection of this.

Trichopterans are usually regarded in literature as the main invertebrate predators of black fly larve, specially the families Hydropsychidae, Limnophilidae and Ryacophilidae (Kuralova and Olejnicek, 1985; Schorscher, 1991; Alencar, et al., 1999), so the correlation between Hydropsychidae and Simuliidae abundances is consistent with the literature, although the weight of its effects as predators on black fly larvae, inferring from the correlations and canonical loadings observed,

B

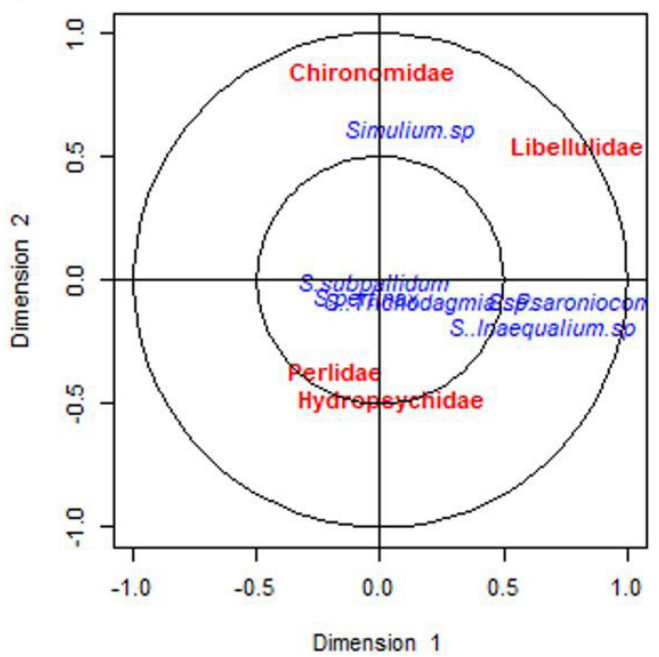

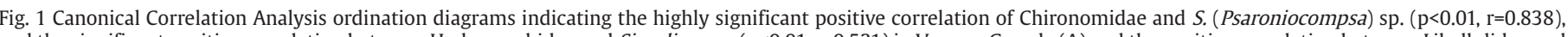

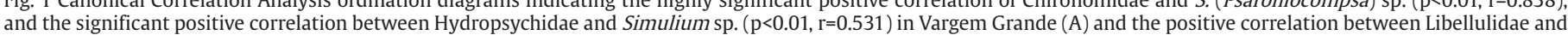
S. (Psaroniocompsa) sp. $(\mathrm{p}<0.01, \mathrm{r}=0.683)$ and Simulium sp. $(\mathrm{p}<0.05, \mathrm{r}=0.450)$ and the correlation of Chironomidae to Simulium sp. $(\mathrm{p}<0.01, \mathrm{r}=0.544)$ in Pau da Fome $(\mathrm{B})$. 
was coherent to what would be expected in Vargem Grande but unexpectedly low in Pau da Fome.

Libellulidae has been shown to be a black fly larvae predator in the literature (Gorayeb and Pinger, 1978; Crosskey, 1990), however its effect on black fly larvae populations has not been approached on previous studies, with the exception of Santos-Junior et al.(2006), in which the authors verified a small presence of black fly larvae in the stomach content of these organisms which contrasts to the high correlations observed in the present study, suggesting that different drivers other than predation may be influencing this pattern.

There are already reports in the literature predation on black fly larvae by larvae of Hydropsychidae (Trichoptera), Pyralidae (Lepidoptera), Libellulidae (Odonata) and Perlidae (Plecoptera) has been detected by means of stomach dissection and serological tests (precipitine and immuno difusion) (Gorayeb and Pinger, 1978; Gorayeb and Mok, 1982; Andrade, 1992; Ferreira, 1996).

The patterns of correlations between black fly larvae and its potential predators is consistent with what would be expected of organisms that exercise mutual population regulation, however the lack of literature (Hart, 1986; Malmqvist and Sackmann, 1996) on the effect of biotic interactions on black fly populations pose a challenge on the understanding of this mechanics, thus further studies like the present one are needed in order to confirm and unveil the extent of predator regulation on black fly distributions.

Due to the dynamic nature of density-dependent processes such as predation, negative and positive correlation may alternate in different moments, so further studies that address the seasonal dynamics could allow a better interpretation of the preliminary patterns that were observed. It is also important to state that these correlations don't necessarily imply causality nor interaction, so it is possible that abiotic factors such as habitat preferences may be influencing the patterns of association. However, in the light of the literature about potential black fly predators it would be reasonable to hypothesize that the results could suggest causality, although this should be further investigated possibly through manipulative experiments to be confirmed.

Studies on trophic relationships are key elements to determine the role of organisms in community structure, which has rarely been studied in black flies. In addition, studies on the potential black fly predators are needed to offer information for future integrated methods of controlling these insects, since some species in this family are of medical and veterinary importance.

\section{Acknowledgments}

The authors would like to thank the staff of park guards of the Pedra Branca State Park and to Nira Beatriz Mendes Ferreira for the help with the field work and to the staff of the Ecologia de Macroinvertebrados Aquáticos e Insetos Vetores research group of UEZO for all the support.

\section{Conflicts of interest}

The authors declare no conflicts of interest.

\section{Author's contributions}

RF contributed with the experimental design, data analysis and manuscript writing, SSS contributed in the field data sampling and organism identifications, TND contributed with data analysis and manuscript review, TRC and CAF contributed in the field data sampling and organism identification, LHGA supervised the organism identification and contributed to the manuscript writing.

\section{References}

Adler, P. H., Currie, D. C., Wood, D. M., 2004. The Black Flies (Simuliidae) of North America. Cornell Univ. Press, Ithaca, $941 \mathrm{pp}$.

Adler, P.H., 2019. World Blackflies (Diptera: Simuliidae): A Comprehensive Revision of the Taxonomic and Geographical Inventory [2019]. Available in: https://biomia.sites.clemson.edu/pdfs/blackflyinventory. pdf (accessed 01 March 2019).

Alencar, Y.B., Hamada, N., Magni- Darwich, S., 1999. Stomach content analysis of potential predators of Simuliidae (Diptera: Nematocera) in two Lowland forest streams, Central Amazonia, Brazil. An. Soc. Entomol. Bras. 28 (2), 327-332.

Allan, J. D., 1995. Stream Ecology: Structure and Function of Running Waters. Chapman and Hall, London, 388 pp.

Andrade, H. T. A., 1992. Estudo da simulidofauna das bacias hidrográficas do Rio Grande do Norte. Master of Science Thesis. Instituto Nacional de Pesquisas da Amazônia, Universidade Federal do Amazonas.

Angrisano, E. B., 1995. Metodologia para su Estudio. In: Lopretto, E.C., Tell, G. (Eds.), Insecta Trichoptera in Ecosistemas de Aguas Continentales. Ediciones Sur, La Plata, Argentina, pp. 1199-1224.

Araújo-Coutinho, C. J. P. C., Nascimento, E. S., Figueiró, R., Becnel, J. J., 2004. Seasonality and prevalence rates of microsporidia in Simulium pertinax (Diptera: Simuliidae) larvae in the region of Serra dos Órgãos, Rio de Janeiro, Brasil. J. Invertebr. Pathol. 85 (3), 188-191.

Blanchet, F. G., Cazelles, K., Gravel, D., 2020. Co-occurrence is not evidence of ecological interactions. Ecol. Lett. 23 (7), 1050-1063.

Buitrago-Guacaneme, A., Sotelo-Londoño, A., Pinilla-Agudelo, G. A., García-García, A., Moncada, L. I., Adler, P. H., 2018. Abundance and diversity of black flies (Diptera: Simuliidae) in rivers of the Andean Eastern Hills of Bogotá (Colombia), and its relationship with water stream physicochemical variables. Univ. Sci. 23, 291-317.

Carvalho, A. L., Werneck-de-Carvalho, P., Calil, E. R., 2002. Description of the larvae of two species of Dasythemis Karsch, with a key to the genera of Libellulidae occurring in the states of Rio de Janeiro and São Paulo, Brazil (Anisoptera). Odonatologica 31, 23-33.

Coscarón, S., Coscarón-Arias, C. L., 2007. Neotropical Simuliidae (Diptera: Insecta). In Adis, J., Arias, J.R., Rueda-Delgado, G., Wantzen, K.M. (Eds.), Aquatic Biodiversity in Latin America. Pensoft Publishers, Sofia, pp. 685.

Crosskey, R. W., 1990. The Natural History of Blackflies. John Wiley and Sons Ltda, England, 711 pp.

Cuadrado, L. A., Moncada, L. I., Pinilla, G. A., Larrañaga, A., Sotelo, A. I., Adler, P. H., 2019. Black Fly (Diptera: Simuliidae) Assemblages of High Andean Rivers Respond to Environmental and Pollution Gradients. Environ. Entomol. 48, 815-825.

Cummins, K. W., 1992. Invertebrates. In: Calow, P. and Petts, G.E. The Rivers Handbook. Hidrological and Ecological Principes. Blackwell Science, Oxford, 526 pp.

Cummins, K. W., Klug, M. J., 1979. Feeding ecology of stream invertebrates. Annu. Rev. Ecol. Syst. 10, 147-172.

Currie, D. C., Adler, P. H., 2008. Global diversity of blackflies (Diptera: Simuliidae) in freshwater. Hydrobiology 595, 469-475.

Currie, D. C., Craig, D. A., 1988. Feeding strategies of larval black flies. In: Kim, K.C., Merritt, R.W. (Eds.), Black Flies: Ecology, Population Management, and Annotated World List. Pennsylvania State University Press, University Park, pp. 155-170.

Docile, T. N., Figueiro, R., Gil-Azevedo, L. H., Nessimian, J. L., 2015. Water pollution and distribution of the blackfly (Diptera: Simuliidae) in the Atlantic Forest, Brazil. Rev. Biol. Trop. 63, 683-693.

Docile, T. N., Rosa, D. C. O., Figueiró, R., Nessimian, J. L., 2016. Urbanisation alters the flow of energy through stream food webs. Insect Conserv. Divers. 9, 416-426. 
Ferreira, A. C. R., 1996. Estudo da fauna de Perlidae (Plecoptera) em Dois Igarapés da Amazônia Central. Master of Science Thesis. Instituto Nacional de Pesquisas da Amazônia, Universidade Federal do Amazonas.

Figueiró, R., Araújo-Coutinho, C. J. P. C., Gil-Azevedo, L. H., Nascimento, E. S., Monteiro, R. F., 2006. Spatial and temporal distribution of blackflies (Diptera: Simuliidae) in the Itatiaia National Park, Brazil. Neotrop. Entomol. 35, 542-550.

Figueiró, R., Calvet, A., Gil-Azevedo, L. H., Docile, T. N., Monteiro, R. F., Maia-Herzog, M., 2015. Evidence of phenotypic plasticity of larvae of Simulium subpallidum Lutz in different streams from the Brazilian Cerrado. Rev. Bras. Entomol. 59, 30-33.

Figueiró, R., Gil-Azevedo, L. H., 2010. The role of the Neotropical blackflies (Diptera: Simuliidae) as vectors of the onchocerciasis: a short overview of the ecology behind the disease. Oecol. Aust. 14, 745-755.

Figueiró, R., Gil-Azevedo, L. H., Maia-Herzog, M., Monteiro, R. F., 2012. Diversity and microdistribution of blackfly (Diptera: Simuliidae) assemblages in the tropical savanna streams of the Brazilian cerrado. Mem. Inst. Oswaldo Cruz 107, 362-369.

Figueiró, R., Maia-Herzog, M., Gil-Azevedo, L. H., Monteiro, R. F., 2014. Seasonal variation in black fly (Diptera: Simuliidae) taxocenoses from the Brazilian Savannah (Tocantins, Brasil). J. Vector Ecol. 39, 321-327.

Figueiró, R., Nascimento, E. S., Gil-Azevedo, L. H., Maia Herzog, M., Monteiro, R. F., 2008. Local distribution of blackfly (Diptera: Simuliidae) larvae in two adjacent streams: the role of water current velocity in the diversity of blackfly larvae. Rev. Bras. Entomol. 52, 452-454.

Gamboa, M., Chacón, M. M., Segnini, S., 2009. Diet composition of the mature larvae of four Anacroneuria species (Plecoptera: Perlidae) from the venezuelan Andes. Aquat. Insects 31, 409-417.

Garcia-Domingo, J. L., Saldaña, J., 2008. Effects of heterogeneous interaction strengths on food web complexity. Oikos 177 (3), 336-343.

Ginarte, C. A., Andrade, C. F., Campos-Gaona, J., 2003. Larvas de simulídeos (Diptera: Simuliidae) do Centro Oeste, Sudeste e Sul do Brasil, parasitadas por Microsporídeos (Protozoa) e Mermitídeos (Nematoda). Iheringia Ser. Zool. 93, 325-334.

Gorayeb, I. S., Mok, W. Y., 1982. Comparison of capillary tube and immunodiffusion precipitin tests in the detection of Simulium fulvinotum larval predators. Cienc. Cult. 34, 1662-1668.

Gorayeb, I. S., Pinger, R. R., 1978. Detecção de predadores naturais das larvas de Simulium fulvinotum Cerqueira e Mello, 1968 (Diptera: nematocera). Acta Amazon. 8, 629-637.

Gotelli N. J., Entsminger, G.L., 2009. EcoSim: Null Models Software for Ecology, v.7. Acquired Intelligence Inc and Kesey-Bear. Available in: garyentsminger.com/ecosim (accessed 25 January 2020).

Gotelli, N. J., Ulrich, W., 2012. Statistical challenges in null model analysis. Oikos 121, 171-180.

Hadi, U. K., Soviana, S., Rohmah, I. L., 2019. Diversity and ecology of black flies in tea plantation area of Puncak Bogor, Indonesia. Acta Trop. 199, 104986.

Hamada, N., Adler, P. H., 2001. Bionomia e chave para imaturos e adultos de Simulium (Diptera: Simuliidae) na Amazônia Central, Brasil. Acta Amazon. 31, 109-132.

Hamada, N., McCreadie, J. W., Adler, P. H., 2002. Species richness and spatial distribution of black flies (Diptera: Simuliidae) in streams of central Amazonia, Brazil. Freshw. Biol. 47, 31-40.

Harding, J., Colbo, M. H., 1981. Competition for attachment sites between larvae of Simuliidae (Diptera). Can. Ent. 113, 761-763.

Hart, D. D., 1986. The adaptive significance of territoriality in filterfeeding larval black flies (Diptera: simuliidae). Oikos 46, 88-92.
Hemphill, N., 1988. Competition between two stream dwelling filterfeeders, Hydropsyche oslari and Simulium virgatum. Oecologia 77 (1), 73-80.

Hershey, A. E., Merritt, R. W., Miller, M. C., McCrea, J. S., 1996. Organic matter processing by larval black flies in a temperate woodland stream. Oikos 75, 524-532.

Kuralova, M., Olejnicek, J., 1985. Predaceous larvae of caddisflies as natural enemies of blackfly larvae (Diptera, Simuliidae) under conditions of South Bohemia. Folia Parasitol. (Praha) 32, 375-376.

Kuvangkadilok, C., Boonkemtong, C., Phayuhasena, S., 1999. Distribution of the larvae of blackflies (Diptera: Simuliidae) at Doi Inthanon National Park, northern Thailand. Southeast Asian J. Trop. Med. Public Health 30, 328-337.

Luz, S. L. B., Crainey, J. L., Shelley, A. J., Rubio, M., 2014. Outstanding insecurities concerning the use of an Ov16-based ELISA in the Amazonia onchocerciasis focus. Mem. Inst. Oswaldo Cruz 109 (4), 506-509.

Malmqvist, B., Adler, P. H., Kuusela, K., Merritt, R. W., Wotton, R. S., 2004. Black flies in the boreal biome, key organisms in both terrestrial and aquatic environments: a review. Ecoscience 11, 187-200.

Malmqvist, B., Sackmann, G., 1996. Changing risk of predation for a filter-feeding insect along a current velocity gradient. Oecologia 108, 450-458.

Nascimento, E. S., Figueiró, R., Becnel, J. J., Araújo-Coutinho, C. J. P. C., 2007. Influence of temperature on microsporidia infections in a natural population of Simulium pertinax Kollar, 1832 (Diptera; Simuliidae). Braz. J. Biol. 67, 519-526.

Olifiers, M. H., Dorville, L. F. M., Nessimian, J. L., Hamada, N., 2004. A key to Brazilian genera of Plecoptera (Insecta) based on nymphs. Zootaxa 651, 1-15.

Pavitra, P. P., Low, V. L., Tan, T. K., Lim, Y. A. L., Ya'cob, Z., 2020. Temporal variation in diversity and community structure of preimaginal blackflies (Diptera: Simuliidae) in a tropical forest reserve in Malaysia. Acta Trop. 202, 220.

Peckarsky, B. L., 1984. Predator-prey interactions among aquatic insects. In: Resh, V.H., Rosenberg, D.M. (Eds.), The Ecology of Aquatic Insects. Praeger Publisher, New York, pp. 196-254.

Pepinelli, M., Trivinho-Strixino, S., Hamada, N., 2005. Imaturos de Simuliidae (Diptera: Nematocera) e caracterização de seus criadouros no Parque Estadual Intervales, SP, Brasil. Rev. Bras. Entomol. 49, 527-530.

Pes, A. M. O., Hamada, N., Nessimian, J. L., 2005. Chaves de identificação de larvas para famılias e gêneros de Trichoptera (Insecta) da Amazônia Central, Brasil. Rev. Bras. Entomol. 49, 181-204.

Rey, L., 2001. Parasitologia. 3a ed. Guanabara-Koogan, Rio de Janeiro, 856 pp.

Rohmah, I. L., Hadi, U. K., Soviana, S., 2018. Larval breeding habitat of Simulium (Diptera: Simuliidae) around stream of waterfall areas of Bogor forest management unit. J. Entomol. Zool. Stud. 6, 3167-3172.

Santos-Junior, J. E., Strieder, M. N., Fiorentin, G. L., Neiss, U. G., 2006. Velocidade da água e a distribuição de larvas e pupas de $S$. (Chirostilbia) pertinax (Kollar) (Diptera, Simuliidae) e macroinvertebrados associados. Rev. Bras. Entomol. 51 (1), 62-67.

Schorscher, J. A., 1991. Assessing the importance of Hydropsychidae larvae as predators of Simulium damnosum s.l., the vectors of river blindness in West Africa. In: Tomaszewski, C. (Ed.), International Symposium on Trichoptera, 6, 1991, Poznan, Poland. Proceedings. Poznan, Poland: Adam Mickiewicz University Press, pp. 105-115.

Siegfried, C. A., Knight, A. W., 1976. Prey selection by a setipalpian stonefly nymph, Acroneuria (Calineuria) californica Bank (Plecoptera: perlidae). Ecology 57, 603-608. 
Silva, S.S.P., Guedes, P.G., Almeida, J.C., Cruz, A.P., 2019. Bionomics and biology of bats (Mammalia - Chiroptera) in an Atlantic forest remnant: Parque Estadual da Pedra Branca (Rio de Janeiro, Brazil). Natur Onl. 17(2), 1-15.

Srisuka, W., Takaoka, H., Otsuka, Y., Fukuda, M., Thongsahuan, S., Taai, K., 2015. Seasonal biodiversity of black flies (Diptera: Simuliidae) and elevation of ecological factors influencing species distribution at Doi Pha Hom Poh National Park, Thailand. Acta Trop. 149, 212-219.

Stone, L., Roberts, A., 1990. The checkerboard score and species distributions. Oecologia 85, 74-79.
Vallejo, L. R., Campos, R. M., Santos Júnior, W. M., 2009. Contribuição ao estudo dos conflitos territoriais no Parque Estadual da Pedra Branca. In: Mendes, C.P.A., Bandeira, F.C.S. (Coords.), Ciência para Gestão ou Gestão para a Ciência? Instituto Estadual do Ambiente, Rio de Janeiro, pp. 6-9.

Werner, D., Pont, A. C., 2003. Dipteran predators of Simuliid blackflies: a worldwide review. Med. Vet. Entomol. 17, 115-132.

Wiggins, G. B., 1996. Larvae of the North America Caddisfly Genera (Trichoptera). University of Toronto Press, Toronto. Available in: https:// www.jstor.org/stable/10.3138/j.ctt130jwx3 (accessed 31 July 2020). 